\title{
A homogenizációs technika alkalmazása porózus anyagokra
}

\author{
Fülöp Tibor*
}

\section{Bevezetés}

Az elmúlt évtizedben számos kutatás folyt a klasszikus anyagtörvények kiterjesztésére, képessé tételére heterogén testek kezelésére. A kifejlesztett eljárások közül a legmegfelelöbbeknek a homogenizációs technikák [1] tủnnek. Ezek közös elvi alapja a heterogén test felosztása apró elemi cellákra, amelyeken belül a vizsgált tulajdonságok már homogénnek tekinthetőek. Ez a lépés a lokalizáció. Az elemi cellák lokális (helyi) tulajdonságaiból állíthatjuk elö a heterogén darab (globális) tulajdonságait, ezt homogenizációnak nevezünk. A gyakorlatban három jelentősebb homogenizációs technika terjedt el:

- növekményes (differential method),

- önbeálló (self consistent),

- és Mori - Tanaka módszer.

Az első két módszer közös jellemzője, hogy az elemi cella - porózus anyag esetén egy izolált üreg és a környező anyag - viselkedésének elemzésére alkalmas fizikai modellek segítségével meghatározott tulajdonságokat terjeszti ki a teljes testre. A kiterjesztés többé kevésbé összetett matematikai eljảrások felhasználásával történik, és általában viszonylag egyszerũ eredményre vezet. A Mori-Tanaka módszer fizikai alapokkal nem rendelkezik, az eredményt általában összehasonlításként, illetve ellenörzésként használják.

Jelen munkában a vizsgálatok körét a porózus (mikroüregeket tartalmazó) anyagokra szükítjük, figyelembe véve a diffúziós folyamatok és a képlékeny alakváltozás hatását is. Ilyen anyagok tulajdonságainak ismeretére van általában szükség egyes melegalakváltozási folyamatok (kúszás, szuperképlékeny alakítás) modellezésénél, illetve a porkohászati eljárások vizsgálatánál. A lokalizációs feladat megoldása után a homogenizáció egy lehetséges módját mutatjuk be.

\footnotetext{
- Doktorjelölt, Miskolci Egyetem, Mechanikai Technológiai Tanszék

Tudományos vezetõ: Prof.Dr. Tisza Miklós
} 


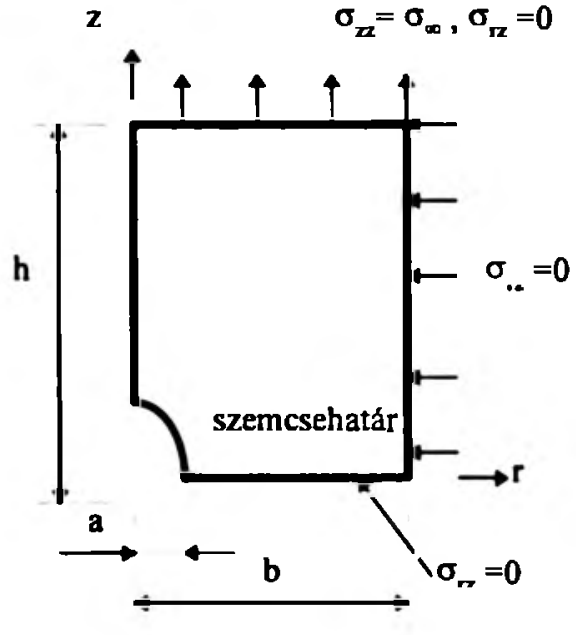

1. ábra

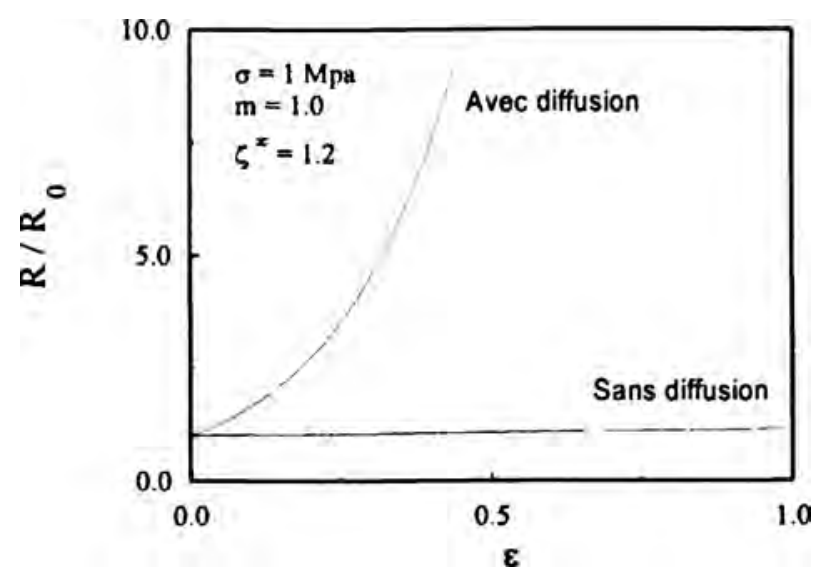

2. ábra

A diffúzió hatása az üreg növekedési sebességére

\section{A lokalizációs feladat megoldása}

A heterogén anyagokra vonatkozó anyagtörvény kidolgozásának első lépése a lokalizációs feladat felírása, illetve megoldása. A feladat leírása az 1.ábrán látható, az izolált mikroüreg növekedésének vizsgálatánál figyelembe vesszük a szemcsehatáron lejátszódó diffúzió [2] és az üreget körülvevő mátrix képlékeny [4] alakváltozásának hatását is. A kiinduló, üreget nem tartalmazó mátrix merev viszkoplasztikus képlékeny, és teljesül rá a térfogat-állandóság feltétele. A feladat zárt alakban sajnos nem oldható meg, ezért a virtuális munka tételének RICE által felírt alakját használjuk [3]. Az optimalizáláshoz felhasznált sebességmező alakja:

$\dot{\bar{u}}=\alpha \dot{\bar{u}}_{k}+\beta \dot{\bar{u}}_{d}$

ahol $a$ és $b$ meghatározandó paraméterek, $\dot{\vec{u}}_{k}$ a BUDIANSKY és TSAI. [4] által képlékeny és $\dot{\bar{u}}_{d}$ a CHUANG és TSAI. [2] által diffúziós növekedésre adott megoldás. Az egyes sebességmezőket az [5] referencia tartalmazza. A feladat, mivel az optimalizálásnál két paramétert alkalmazunk, és ezek között az $a+b=1$ összefüggés írható fel, visszavezethető az

$F=A_{1} \alpha^{m+1}+A_{2} \alpha^{2}+A_{2} \alpha+A_{1}$

nemlineáris egyenlet megoldására. Itt $m$ a viszkoplasztikus mátrixra jellemző sebességérzékenység $\left(\sigma=k_{\dot{\varepsilon}}^{m}\right), a$ az ismeretlen amplitúdó, $A_{\imath}$ pedig a Rice-féle funkcionálból határozható meg elemi, bár kissé hosszadalmas számítások után:

$A_{1}=\frac{n}{n+1} \int_{0}^{H} \int_{\sqrt{1-\frac{z^{2}}{R^{2}}}}^{B}\left(\frac{\sqrt{3}}{3} \frac{\sqrt{3 \dot{\varepsilon}^{2} r^{4}+4 B^{2}}}{\dot{\varepsilon} r^{2}}\right)^{n+1} \frac{r}{R} d r d z ;$ 
$A_{-}-\frac{a^{3}}{L^{3}} \frac{\dot{u}_{s d}^{2}}{24 R^{2} \dot{\varepsilon}^{2}}\left(D^{2} \quad !\right)^{3}$

$A_{3}=\frac{S}{\sigma} \frac{B^{2}}{2 R^{2} \dot{\varepsilon}}\left(\dot{\underline{u}}_{z a}-H \dot{\varepsilon}\right)-\frac{u^{3}}{L^{3}} \frac{\dot{u}_{z d}^{2}}{12 R^{2} \dot{\varepsilon}^{2}}\left(n^{2}-1\right)^{3}-\frac{\sigma_{\infty}}{\sigma} \frac{\dot{u}_{z d}}{2 R^{2} \dot{\varepsilon}}\left(\underline{Q}^{2}-1\right)$

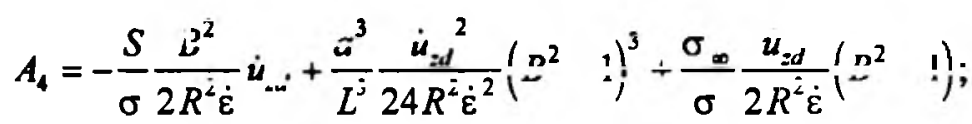

$A$ (3-6) egyenletekben található paraméterek értelmezése az 1.ábrán található.

A (2) - ben található egyenlet zárt alakban csak $m$ speciális értékeire oldható meg. Az általános megoldás numerikus eljárás segítségével határozható meg.

\section{Az alkalmazott homogenizációs eljárás}

A Bevezetésben említett homogenizációs technikák közül a legegyszerübben kivitelezhető a növekményes módszer. RICE (1970) munkája alapján a globális feszültségpotenciált a helyi potenciállal az alábbi összefüggés kapcsolja össze:

$\Phi(\Sigma)=\frac{1}{V_{r}} \prod_{V_{v}}^{p} \phi(\sigma) d V$,

ahol $V_{\mathrm{r}}$ egy üreg térfogata, $\mathrm{V}_{\mathrm{v}}$ a teljes térfogat üregek által elfoglalt része. DuvA és HUTCHINSON [6], illetve LEE és MEAR [7] a fenti összefüggésre támaszkodva írta fel a képlékeny potenciál változását néhány üregnek az anyagban történő eloszlatásakor:

$\Phi(\Sigma)=\phi(\Sigma)+f \frac{\partial \Phi}{\partial f}$

ahol $\partial \Psi / \partial f$ a lokalizáció során számítható. Megmutatható, hogy a Rice féle funkcionál használata esetén a képlékeny potenciál változása kielégíti a következő összefüggést:

$\frac{\partial \Phi}{\partial f}=\varphi(\sigma)-\frac{F_{\min }}{V_{c}}$

Itt $\varphi(i ́)$ a mátrix képlékeny potenciálja és $F_{\min }$ a Rice funkcionál minimum-értéke. A lokalizációs feladat megoldása szolgáltatja ezt a minimum értéket. A mátrixra a képlékeny potenciál értékét a jól ismert

$\varphi(\sigma)=\frac{\varepsilon_{0} \sigma_{0}}{n+1}\left(\frac{\sigma}{\sigma_{0}}\right)^{n+1}$

összefüggés segítségével határozható meg. Itt $n=1 / m$. 


\section{Eredmények}

A lokalizációs és a homogenizációs feladat megoldása jelzi, hogy az átmeneti növekedési mód, vagyis a diffúzió és a képlékeny alakváltozás együttes hatása az üregek növekedési sebességének, így a porozitásnak is a jelentős növekedését okozza. A 2. ábrán egy izolált üreg dimenziótlanított sugarának változását mutatjuk be. A növekedés magyarázatát a diffúziós folyamat során az üreget a szemcsehatáron elhagyó atomok szemcsehatárt torzító, igy a helyi feszültségkoncentrációt növelö hatásának tulajdoníthatjuk. Az anyagtörvény állandóinak változása ezen tendencia meglétét igazolja.

\section{Következtetés}

Jelen munka a merev - viszkoplasztikus mátrixban elhelyezkedő üreg növekedését, illetve az anyag tulajdonságainak változását vizsgálta. Két növekedési módot vettünk figyelembe, az egyik az üreget elhagyó atomok diffúziójából, míg a másik az üreget körülvevő mátrix képlékeny alakváltozásából adódó üregnövekedés. A számítások során az üreg torzulásának hatását elhanyagoltuk, feltételezve, hogy a kezdetben tengelyszimmetrikus üregek megörzik egyensúlyi alakjukat a teljes alakváltozás során.

Az eredmények jól mutatják, hogy a két növekedési mód együttes figyelembevétele a növekedési sebességnek a diffúziós atommozgás szemcsehatárdürvító hatásából következő növekedését eredményezi.

\section{Köszönetnyilvánítás}

Jelen munka részben a Francia Kormány kutatási ösztöndíjnak köszönhetően az Ecole des Mines de Saint-Etienne laboratóriumában folyt; a szerzỏ köszönettel tartozik Dr. Helmuth Klöckernek, aki a munka ezen részének irányitását végezte.

\section{Irodalom}

[1] ChristiEnSEn, J. Mech. Phys. Solids, V38, No.3., pp.379-404, 1990

[2] ChUANG-KAGAWA-RiCE-SiLlS, Acta. Metall. V27 pp.265-284, 1979

[3] NEEDLEMAN-RICE, Acta. Metall. V28 pp1315-1332, 1980

[4] BUDIANSKY-HUTCHINSON-SLUTSKY, "Mechanics of Solids", The $R$. Hill 60th anniversary volume, Ed. Hopkins H.G., Sewell M.J., pp.13, 1982

[5] FÜLÖP, RoPM'96, 1996, Megjelenés alatt

[6] DUVA-HUCHINSON, Mech.Mater., V3, pp.41, 1984

[7] LEE-MEAR, J. Mech. Phys. Solids, V40, pp.1805, 1992

\section{A szerző adatai}

Fülöp Tibor, doktorjelölt

Miskolci Egyetem, Mechanikai Technológiai Tanszék

H3515, Miskolc-Egyetemváros, Magyarország

Tel.:(36-46) 365-1 11/18-46 ; Fax.: (36-46)363-929 